\title{
Analysis of Changes in Cost Recovery Scheme towards Split Gross in Oil and Gas Companies in ETB Field
}

Ravena Galuh Karisma ${ }^{1 *}$, Nengzih Nengzih ${ }^{1}$

${ }^{1}$ Accounting Study Program, Faculty of Economics and Business, Mercubuana University, Jakarta, Indonesia

\author{
DOI: $10.36348 /$ sjef.2021.v05i03.003 $\quad$ | Received: 27.02.2021 | Accepted: 19.03.2021 | Published: 22.03 .2021 \\ *Corresponding author: Ravena Galuh Karisma \\ Abstract
}

This study aims to determine the analysis of changes in the cost recovery scheme against the gross split of oil and gas companies in the ETB field. Based on previous research, it can be seen that the comparative analysis of the Change in Cost Recovery Scheme to the Gross Split has found that the Gross Split Scheme is superior to the Cost Recovery Scheme. This study took the population and samples from PT Pertamina, the ETB Field subcontractor. These results indicate that Product Sharing Contract (PSC) Gross Split is considered to be superior compared to PSC Cost Recovery and is feasible to implement because this indicator shows a fairly good sensitivity.

Keywords: Cost Recovery, Gross Split, Oil and Gas.

Copyright $\odot$ 2021 The Author(s): This is an open-access article distributed under the terms of the Creative Commons Attribution 4.0 International License (CC BY-NC 4.0) which permits unrestricted use, distribution, and reproduction in any medium for non-commercial use provided the original author and source are credited.

\section{INTRODUCTION}

Indonesia is a rule of law in which there are laws and regulations that are not just a product of functions in the regulatory sector but give shape to values, norms, that live and apply in society and laws [1]. This arrangement is of course in order to maximize the goals of the company or organization. As according to Nengzih [2] states that without organized management or governance, the goals of the company can certainly not be maximized and will not necessarily be achieved. The results of these studies indicate that corporate governance, Environmental Management Accounting (EMA) companies have a small impact on the financial performance of related companies. One of the Indonesian state assets related to society are the activities of oil and gas.

One of the assets of the state or the production branch of the Indonesian economy that is related to the wider community is the activity of oil and natural gas (oil and gas). For natural gas, in general, the proportion of production sharing is $70 \%$ for KKKS and $30 \%$ for Joint Operations. Law No. 22 of 2001 regarding Oil and Gas or Oil and Gas, Article 1 point 19 states that KKS is Production Sharing Contracts or other forms of cooperation contracts in exploration and exploitation activities that are more beneficial to the
State and the results are used for the greatest prosperity of the people. KKS or Cooperation Contract is a Production Sharing Contract and the so-called Production Sharing Contract (PSC) in Indonesia in particular experiencing a few generations as KKS / PSC first generation between 1964 the year 1977, the second generation in 1978 - the year 1987, the third generation in 1988 - in 2001, the fourth generation in 2001 up to now, then the latter is KKS / PSC scheme gross split.

Against the state, the scheme Product Sharing Contract (PSC) Gross Split not sacrifice State Expenditure Budget (APBN) to pay off the cost required to implement the scheme of Product Sharing Contract (PSC) Cost Recovery. The state budget or company budget is usually needed, as stated by Hidayah et al., [3] where the research shows that based on the results of the socialization, participants are enthusiastic about training because they need to implement a household budget. Salim [4] states that the profit sharing system between the Government and the Product Sharing Contract (PSC) occurs after previously being reduced by Cost Recovery. According Marysta et al., [5] stated that overall transactions that occur in the oil and gas contract that is reporting the substance of the transaction, with Cost Recovery contractor declared scalable and reliable and 
appropriate portions. Based on the explanation above, it can be seen that the focus is that changes in Cost Recovery paid to contractors will directly impact the amount of company operating revenue, and what if Cost Recovery changes to Gross Split.

For the contractor, the PSC Gross Split scheme can indirectly force the contractors and subcontractors to do efficiency. And the PSC Gross Split is considered to be a solution for both parties in the oil and gas industry. However, with the PSC Gross Split, it is possible for new things to emerge in the procurement of services and goods for oil and gas business activities that previously used a cost recovery scheme. This is because in the PSC Gross Split the contractor can independently regulate what method, with whom, how long, and the amount of the value of the procurement itself by the contractor without any clear regulations. However, according to Roach et al., [6] expressing another opinion that from a fiscal perspective, this Gross Split PSC has similar characteristics to the royalty regime and this has been successful elsewhere in the world, however, the economy of this royalty regime may not be very suitable if implemented in Indonesia. Where in Indonesia there are a number of fields with low margins, high costs and capital-intensive projects that are located in deep water border areas.

In carrying out the tender, the PSC/PSC contractor will make it possible to find ways that can be profitable effectively and efficiently and this creates an unfair potential in the future in the procurement of services and goods. This is supported by research conducted by Irhma et al., [7] where several oil and gas projects this new policy contract (Gross Split) cannot always be applied because it produces lower economic indicators than the previous policy contract, namely Cost Recovery. This means that Cost Recovery is better than Gross Split. Then another research conducted by Irine Handika et al., [8] revealed that PSC Cost Recovery is still considered quite profitable to run an oil and gas business in Indonesia, although previously the contractor or subcontractor had to bear the burden first, but there would be a change in costs for oil and gas exploration and production. Irham et al., [7], Khafid et al., [9], Giranza et al., 10], Mangundjaya et al., [11], have another view that according to their economic calculations, the PSC Cost Recovery model still gives better results compared to Gross PSC Split.

Based on the Minister of Energy and Mineral Resources Regulation No. 08 of 2017 concerning the Gross Split Production Sharing Contract, Article 25 concerning the Gross Split Production Sharing Contract (Permen Gross Split). The Gross Split Permen changed the KKS scheme which was originally a Cost Recovery. Then the Cooperation Contract that the government will offer through an auction to contractors is the Gross Split Scheme Cooperation Contract and the transition between the Cost Recovery Scheme Cooperation Contract and the Gross Split Scheme Cooperation Contract. At the beginning of 2017 a new regulation was announced by the Ministry of Energy and Mineral Resources, namely the transition from PSC Cost Recovery to PSC Gross Split. By applying this scheme method, there is great hope from the government that more and more investors will be attracted to enter and join the oil and gas industry in Indonesia, meaning that subcontractors will find it easy to find investors who want to enter the oil and gas world. This is supported by research conducted by Henandoko and Imanullah [12] where the results of the study show that in the Gross Split system the procurement of goods or services is carried out independently by the contractor / subcontractor. With the Gross Split, in procuring goods and or services, the contractor or subcontractor is no longer monitored, because the state has not replaced the Cost Recovery so that the contractor is given more flexibility to buy their own needs.

Furthermore, William et al., [13] describe the results of their research on investment certainty even though the oil price rises or falls using the production sharing contract method or the Gross Split method, if the oil price is less attractive, the contractor or subcontractor can still get an additional split. Then Muhammad Ariyono and Eka Kusuma Dewi [14], stated that the PSC Gross Split contract research gave better results compared to the PSC Cost Recovery contract. Furthermore, Novianita Rulandari et al., [15] explained that with the PSC Gross Split method the procurement process carried out by contractors to subcontractors is simpler, there is no need for the approval process by SKK Migas, because all oil and gas operating costs are the full responsibility of the contractor and subcontractor. The more efficient and the greater the profit that can be obtained by the contractor or subcontractor.

Other research was also carried out by Nanang Sahroini et al.,[16] where the results of their research concluded that the main factor that causes gross failure lies in the implementation of the split in the company is failure to achieve cost efficiency, PSC Gross Split is considered to be successful and sustainable if the company can achieve efficiency. cost. Ariel Bergman et al., [17] stated that the PSC Gross Split is actually not better or not superior to PSC Cost Recovery, however, this PSC Gross Split method provides a better and clearer structure. Mike Cuthbertson et al., [18] stated another opinion that in general Cost Recovery requires a lot of revision and changes in prospects for oil and gas investment in Indonesia. Meanwhile, the Gross Split is seen as more efficient, especially for investment. Dr. Taiwo Adebola Ogunleye et al., [19] stated that PSC is a better choice for the development of offshore oil reserves because it frees the government to bear any financial burden. Mega Puspita Aisyah Rahman [20], 
Kasman Arifin ZA et al., [21] both concurrently reveal that when viewed from the government side, the Gross Split scheme which is considered better, in addition to efficient and fair policies, adds income to the state. When viewed from a contractor or subcontractor's perspective, the Gross Split scheme is considered quite heavy because all costs will be borne by the contractor / subcontractor alone.

Based on some pemapaan description and discussion above, the writer needs to examine issues related to Analysis Scheme Change Cost Recovery against Gross Split on Oil and Gas Field Company ETB.

\section{LITERATURE REVIEW AND HYPOTHESIS DEVELOPMENT \\ Product Sharing Contract (PSC)}

PSC or Production Sharing Contract is a model that develops from the concept of production sharing agreements and is known in Indonesian customary law. Term cooperation contract by Law Number 222001 related to the oil and gas (oil and gas) is a contract $b$ entuk cooperation contracts or $b$ agi hasi 1 da lam exploitation activities that benefit the country and the results are used for the welfare of the people. Based on the law related to oil and natural gas where the law is not clear on the understanding Contract Production Sharing Contract (PCS) or Sharing but explanation of the production sharing contracts or Production Sharing Contract (PCS) can be in found in Article 1 paragraph 1 Regulations Government No. 35 of 1994 regarding the requirements and guidelines for oil and gas production sharing contracts (Migas).

\section{Cost Recovery}

According to Satrio (2012, October 20) Cost Recovery is a cost that is then paid by the Government to contractors in reimbursing production costs and investment during the exploration and exploitation process as well as the development of oil and gas blocks carried out in a country.

\section{Gross Split}

Gross Split in the Minister of Energy and Mineral Resources Regulation No. 82017 and its amendments have fulfilled the elements stipulated in Law No. 22, 2001 related to Oil and Gas (Oil and Gas). The material (substantive) thing that is meant to have been fulfilled is that the Gross Split Production Sharing Contract has met the substantive requirements stipulated in Article 6 of Law No. 22 of 2001. So it can be seen that the Production Sharing Contract (PSC) Gross Split is the size of the return on investment and the profits that will be obtained by the Contractor, it really depends on how efficient they are in carrying out petroleum operations.

\section{RESEARCH METHODOLOGY}

This section describes the types of data collected, data sources, data periods, and the methodology used to test this relationship.

\section{Data, Population and Sample}

The population of this study is the ETB Field Operations Cooperation (KSO). The data in this study used several ways including observation / observation by making direct observations in the field according to the sample used, interviews (face-to-face interviews, telephone interviews and interviews via electronic media), documentation contained in the Pertamina ETB Field subcontractor. such as raw data which is then processed using Microsoft Excel. Then, a simulation is done using excel which has been designed to process the data into PSC Cost Recovery and Gross Split schemes. Library (Library Research) by obtaining as many theories or journals as supporting data collected and further processing. In this study, the samples used were related parties who were able to provide real or actual information and had a relationship with the competent oil and gas finance sector, PT Pertamina, the ETB Field subcontractor.

Data Analysis: Data analysis techniques in this study were data reduction, data presentation, and conclusions.

\section{RESULTS AND DISCUSSION RESULT \\ Discussion Parameters}

In the results of data processing using two types of Production Sharing Contract (PCS) schemes, then an analysis of the results of cash flows can be carried out. Through the results obtained, it will be seen whether the Gross Split Production Sharing Contract (PCS) scheme has a good cash flow compared to the Cost Recovery Product Sharing Contract (PSC) scheme. Not only that, but the level of feasibility of a project can also be assessed from several existing Break Event Point indicators. So that, of course, it can clarify that the Gross Split Product Sharing Contract (PSC) scheme is feasible or not to be implemented compared to the Cost Recovery Product Sharing Contract (PSC) scheme.

\section{Parameter Calculation}

In using the second calculation of the Product Sharing Contract (PSC) scheme, the inputs or parameters needed in calculating the Gross Split Product Sharing Contract (PSC) scheme and Cost Recovery in the ETB field include investment costs obtained from investors, operational costs, prices oil and production data.

\section{Production Data}

Production data to be able to produce the value of an NPV and IRR and BEP, the researcher uses data in the ETB field for 15 years, this data and calculation will be one of the inputs in order to calculate the value 
Ravena Galuh Karisma \& Nengzih Nengzih., Saudi J Econ Fin, Mar, 2021; 5(3): 114-125

as a benchmark or reference for what scheme to use next, attached production data at Oil and Gas Company field ETB

Table-1: Oil and Gas Production Data

\begin{tabular}{|l|l|}
\hline Year & Oil Production Volume \\
\hline 2015 & 456 \\
\hline 2016 & 1.432 \\
\hline 2017 & 3.190 \\
\hline 2018 & 5.729 \\
\hline 2019 & 6.914 \\
\hline 2020 & 6.983 \\
\hline 2021 & 5.356 \\
\hline 2022 & 3.732 \\
\hline 2023 & 2.565 \\
\hline 2024 & 1.386 \\
\hline 2025 & 749 \\
\hline 2026 & 405 \\
\hline 2027 & 219 \\
\hline 2028 & 118 \\
\hline 2029 & 64 \\
\hline Total & 39.299 \\
\hline
\end{tabular}

The production yield from the ETB field that has been targeted for the next 15 years is 39,299. The data also includes the annual oil production target.

\section{Operating costs}

Is cost -the cost of which come out every day during the contract stipulated took place between the contractor with the government. This fee includes cumulative costs.

\section{Investment Costs}

Investment costs are expenses whose expenses include tangible as well as intangibles based on a portion of $40 \%$ and $60 \%$.

Table-2: Investment Cost (In MUSD)
\begin{tabular}{|l|l|}
\hline INVESTMENT & COST \\
\hline Tangible & \\
\hline Surface Facility & 18.000 \\
\hline Sumur Injection & 9.000 \\
\hline Sumur Infill & 11.000 \\
\hline Intangible & \\
\hline Sumur Injektor & 25,065 \\
\hline Sumur Infill & 28,935 \\
\hline TOTAL & 92,000 \\
\hline
\end{tabular}

\section{Oil Price}

During the 15 years the contract period is 35 USD / bbl because there is no change in that period. By knowing the oil price, it can also be seen that the Gross revenue earned during the 15 -year contract period. Below is the attached Gross revenue earned during the 15 years of the contract period.

Table-3: Gross revenue

\begin{tabular}{|l|l|}
\hline Total Lifting & $39,299.26 \mathrm{MSTB}$ \\
\hline Price per barrel & $35 \mathrm{USD} / \mathrm{bbl}$ \\
\hline Gross revenue & $1,375,474 \mathrm{MUSD}$ \\
\hline
\end{tabular}

\section{PSC Cost Recovery Scheme Calculation}

Furthermore, analyzing the economic value of the contract system will then evaluate the results of its economic calculations. This cash flow analysis is carried out on the Product Sharing Contract Cost Recovery scheme and then compared between the Gross Split Product Sharing Contract scheme. The Production Sharing Contract (PCS) Cost Recovery scheme will be based on the Fiscal Terms Production Sharing Contract (PCS) Cost Recovery in the ETB field can be explained as follows:

Table-4: Fiscal Cost Termination (In \%)

\begin{tabular}{|l|l|}
\hline \multicolumn{2}{|l|}{ Fiscal Cost Termination } \\
\hline GOI Split (B/T) & 71.15 \\
\hline KKKS Split (B/T) & 28.85 \\
\hline Tax Rate & 48 \\
\hline Investment Credit & 17 \\
\hline DMO Holiday & 5 Year \\
\hline DMO Fee & 15 \\
\hline Depreciation & Declining Balance \\
\hline Depreciation Rate & 25 \\
\hline FTP Total & 20 \\
\hline DMO & 25 \\
\hline
\end{tabular}

Termination of Fiscal Fee is valid for fifteen (15) years of contract of work. The split before oil tax between the government or government and the contractor has a ratio of $71.15 \%$ to $28.85 \%$, which means $80 \%$ for the government or government and $20 \%$ for KKKS. The tax rate applied to the contractor's taxable income is $48 \%$. The investment credit itself is included in the recoverable cost to the contractor, government or government and then carries out a replacement of $17 \%$. DMO Holiday is valid for five (5) years or 60 months when production begins. The amount of DMO Fee that must be paid by contractors to the government is 15 percent. The volume of the applicable DMO is $25 \%$ of the total oil revenue. The depreciation method is the Declining Balance while the depreciation rate is $25 \%$. First Tranche Petroleum accounts for $20 \%$ of the total lifting. After using the Fiscal Terms, the following results were obtained from two parties: 


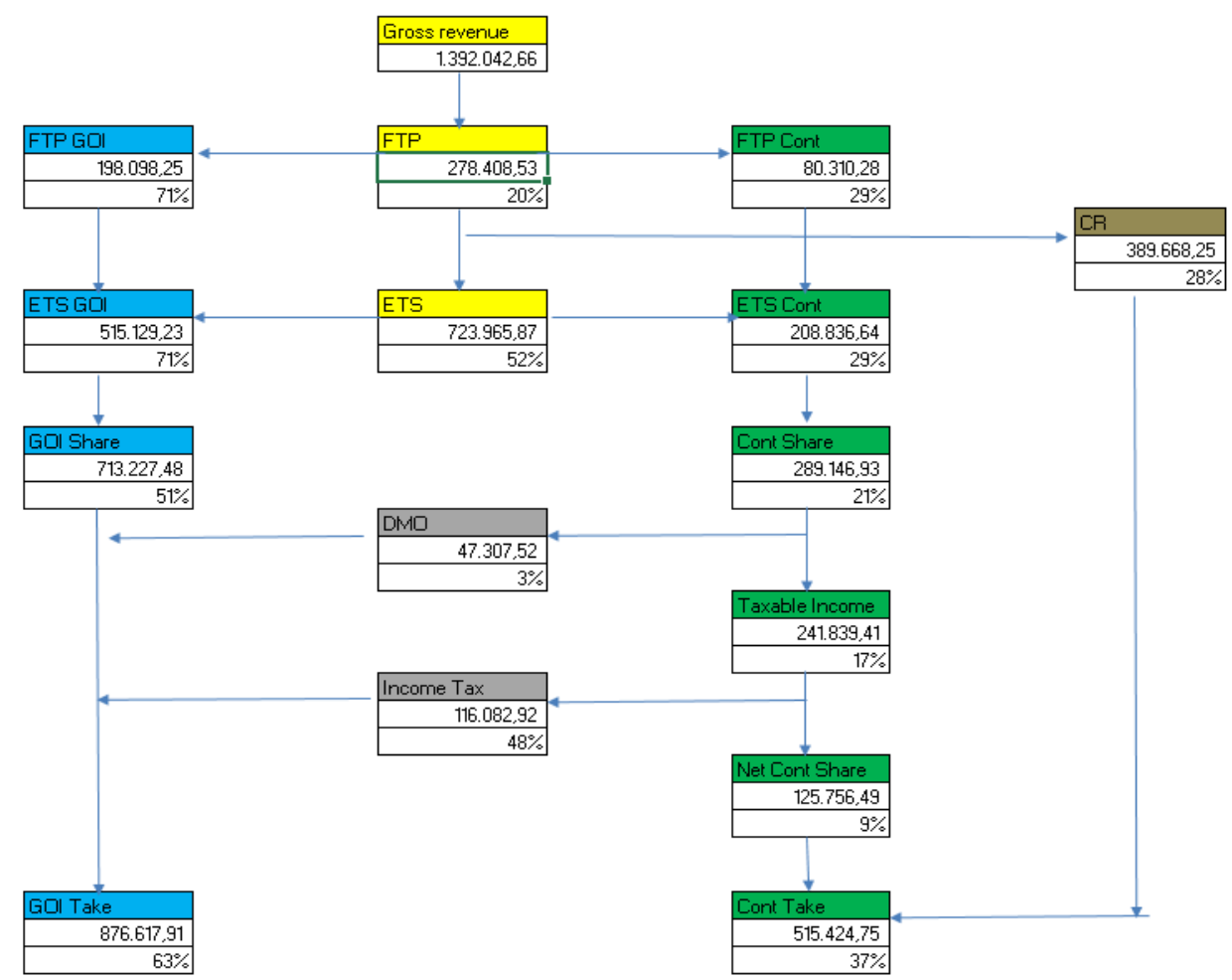

Fig-1: Chart Scheme PSC Cost Recovery

Gross revenue in Figure-1 is 1,392,042.66 MUSD. The contractor's total cost recovery was $515,424.75$ MUSD, then the acquisition of 343,753.81 MUSD was the contractor's acquisition after tax. For the government or government, the proceeds obtained, including taxes from contractors, amounted to 876,617.91 MUSD. The following is the cash flow from the ETB bar using PSC Cost Recovery.
Table-5: Scheme Cash Flow PSC Cost Recovery

\begin{tabular}{|l|l|}
\hline Total Cashflow & $60,064.00$ MUSD \\
\hline
\end{tabular}

The following are profiles that encourage annual cash flow:

Profil Cash Flow Lapangan ETB

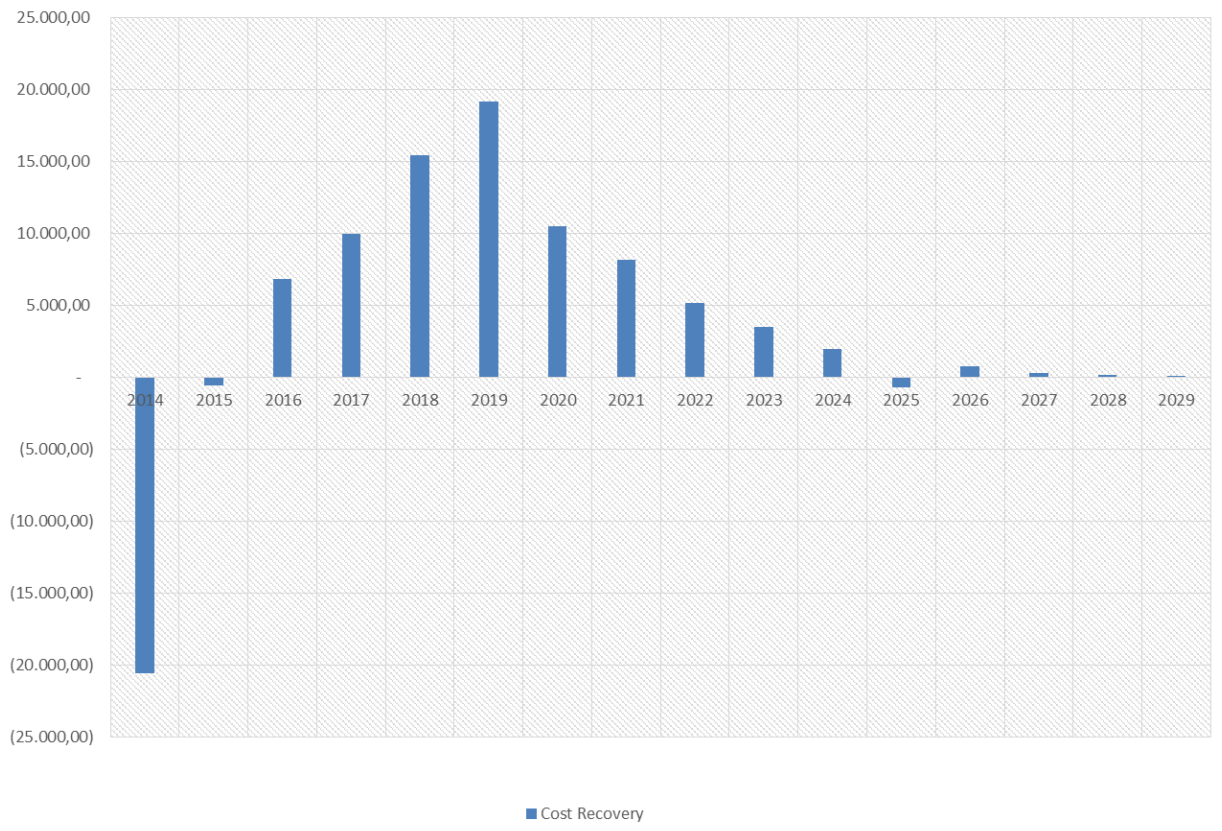

Fig-3: Profile Cash Flow PSC Cost Recovery 
Based on Figure-3 above, it can be seen the cash flow progress of the ETB field in the PSC Cost Recovery scheme. Then, calculations are made on economic indicators such as Net Present Value or NPV, Break Event Points or BEP, Pay Out Time or POT, Discounted Profiability Index or DPI, and Internal Rate of Return or IRR. The following results obtained for the NPV:

Table-6: Indicator PSC Cost Recovery

\begin{tabular}{|c|c|c|}
\hline NPV@10\% & $\$ 54.603,64$ & M US\$ \\
\hline IRR & $47,15 \%$ & $\%$ \\
\hline POT & 2,99 & Year \\
\hline
\end{tabular}

NPV From Table-6 above, it is known that the amount of $10 \%$ obtained during the contract period after the contract period ends is 54,603.64 MUS \$. As for the IRR, the figure is $47.15 \%$. Which means that a project is very feasible to be realized. For the first time, the BEP was achieved at 2.99. This means that this will be achieved when the contract runs in the following year. This means that the project or contract on an ETB field with the Product Sharing Contract Cost Recovery scheme is very feasible to realize and very feasible to obtain investment value from several shareholders.

\section{Gross Split PSC Schematic Calculation}

Currently, in carrying out calculations with the Product Sharing Contract Gross Split scheme. Because the Product Sharing Contract Gross Split scheme has its own split division, it is necessary to determine the split and progressive split variables which are then added to the base split.

Table-7: Indicator PSC Cost Recovery

\begin{tabular}{|c|c|c|c|}
\hline \multicolumn{2}{|c|}{ NPV@10\% } & $\$ 54.603,64$ & M US\$ \\
\hline \multicolumn{2}{|c|}{ IRR } & $47,15 \%$ & $\%$ \\
\hline \multicolumn{2}{|c|}{ POT } & 2,99 & Year \\
\hline \multicolumn{4}{|c|}{ Table-8: Base Split } \\
\hline & \multicolumn{2}{|c|}{ Contractor / KKKS } & Goverment \\
\hline Oil & \multicolumn{2}{|c|}{$43 \%$} & $57 \%$ \\
\hline
\end{tabular}

For the split variable it is influenced by the characteristics of the field, then the progressive split itself is influenced by the number of quantities, the stage of production, and the prevailing oil price. The tax charged to the contractor is $40 \%$.

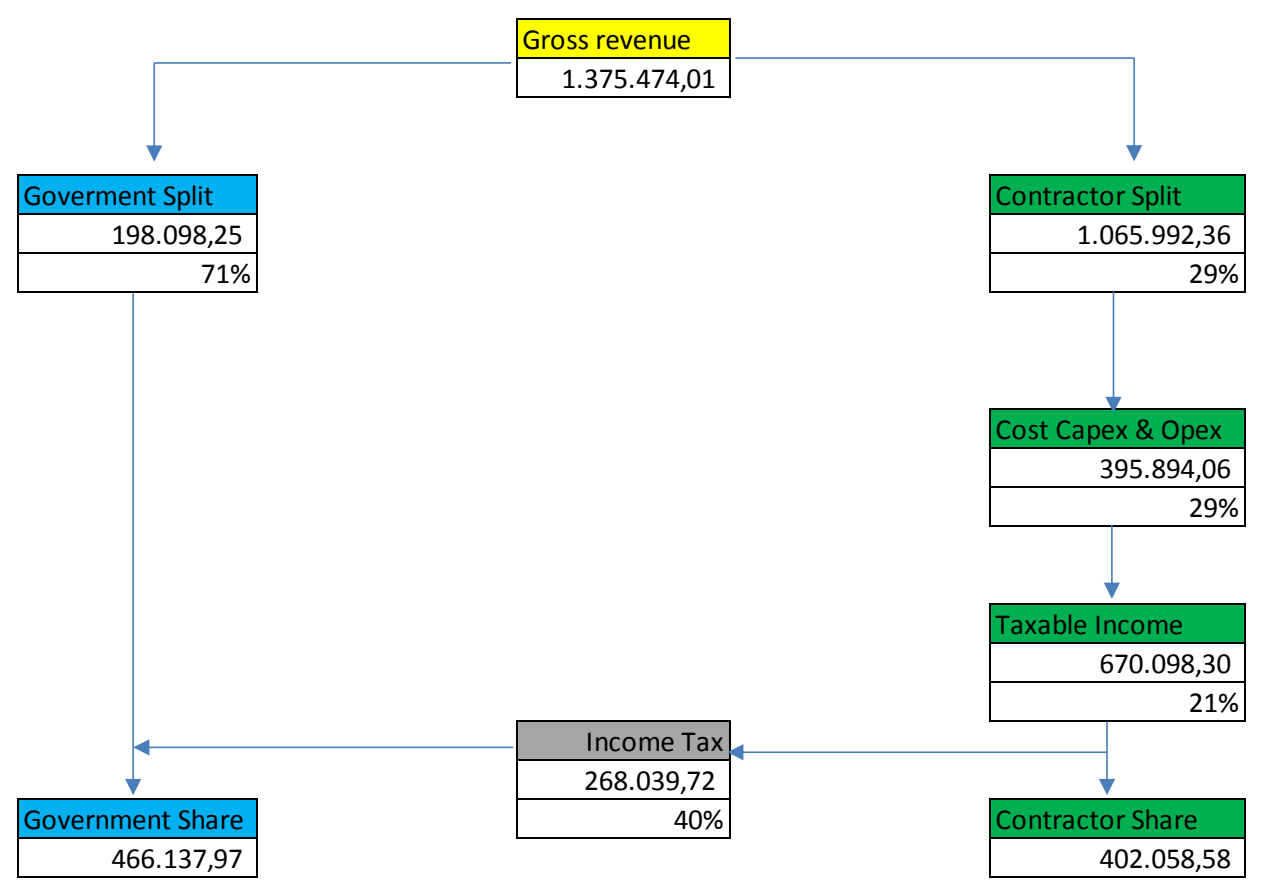

Fig-3: Chart PSC Gross Split

From the PSC scheme in Figure-3 in front of the ETB field, the gross revenue is obtained with a value of $1,375,474.01$ MUSD. The result of the previous split adjustment was $77.50 \%$. It can be seen that the split contractor share is $1,065,992.36$ MUSD. Based on the scheme of the PSC Gross Split there is no cost recovery, so it is necessary to pay $395,894.06$
MUSD during the contract. so that the tax deduction of the contractor is 402,058.58 MUSD. For the government itself, the amount is 466,137.97 MUSD after adding the income from taxes. From the results of these calculations, the cash flow of the ETB field can be calculated using the PSC Gross Split scheme. 


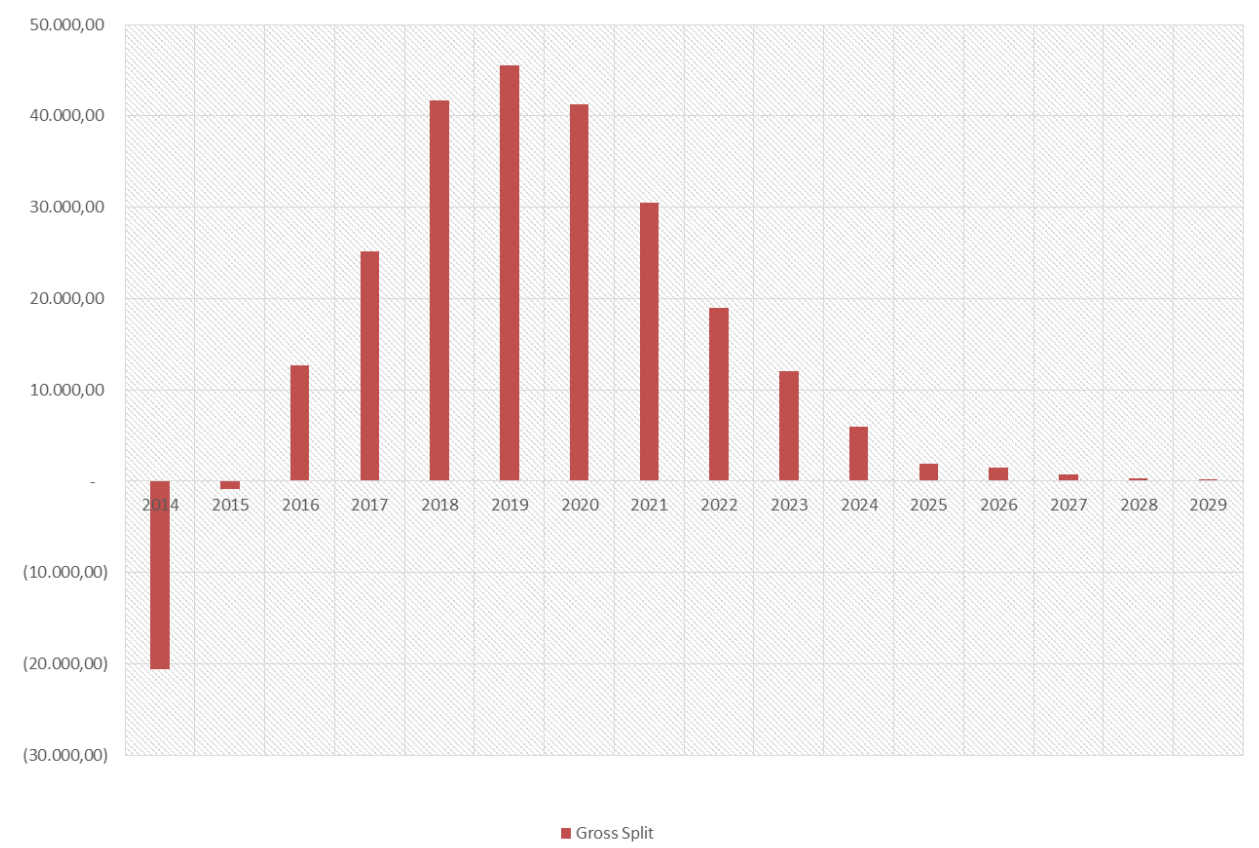

Gambar-4: PSC field cash flow profile with Gross Split scheme

Product Sharing Contract (PSC) Cost Recovery scheme that has been obtained previously, where after obtaining cash flow can then determine the ETB field indicator using the Gross Split scheme.
Indicators include Net Present Value (NPV), BEP (Break Event Point) / POT (Pay Out Time), and Internal Rate of Return (IRR). The amount of NPV withdrawn is $10 \%$.

Table-10: Indicator PSC Gross Split

\begin{tabular}{|c|c|c|}
\hline NPV@10\% & $\$ 197.435,99$ & M US\$ \\
\hline IRR & $85,84 \%$ & \\
\hline POT & 2,18 & Year \\
\hline
\end{tabular}

Based on the data above in Table-9, NPV with a size of $10 \%$ is obtained after the contract period ends, namely 197,435.99 MUSD. Meanwhile, the IRR is $85.84 \%$, which means that the contract is feasible to be implemented and realized. That the field also has the potential to produce oil. For BEP when the first men to achieve a contract that is entered in the three (3) since the start of his contract. With these results it can be said that the project on the ETB field is also feasible to be implemented with the PSC Gross Split scheme

\section{PSC Scheme Comparison}

Next, the researcher will discuss, namely the comparison of the PSC Scheme, between the PSC Gross Split scheme and the PSC Cost Recovery scheme. Comparisons were made to NPV, IRR, BEP, KKKS and GOI.

Table-11: Comparison of Profit Sharing between the Government and Contractors (KKKS)

\begin{tabular}{|l|l|l|}
\hline & PSC Cost Recovery & PCS Gross Split \\
\hline GOI Take & $876,617.91$ & $466,137.97$ \\
\hline Kontraktor Take & $515,424.75$ & $402,058.17$ \\
\hline
\end{tabular}

From Table-11, it can be seen that the revenues of the government and contractors are more profitable when using the Product Sharing Contract Cost
Recovery scheme. For further comparisons, we will focus on Cashflow between the two PSC schemes. 
Table-12: Comparison of Cash Flow

\begin{tabular}{|l|l|}
\hline & Cashflow PSC \\
\hline Cashflow PSC Cost Recovery & $60,064.00$ \\
\hline Cashflow PSC Gross Split & $217,179.58$ \\
\hline
\end{tabular}

Profil Cash Flow Lapangan ETB

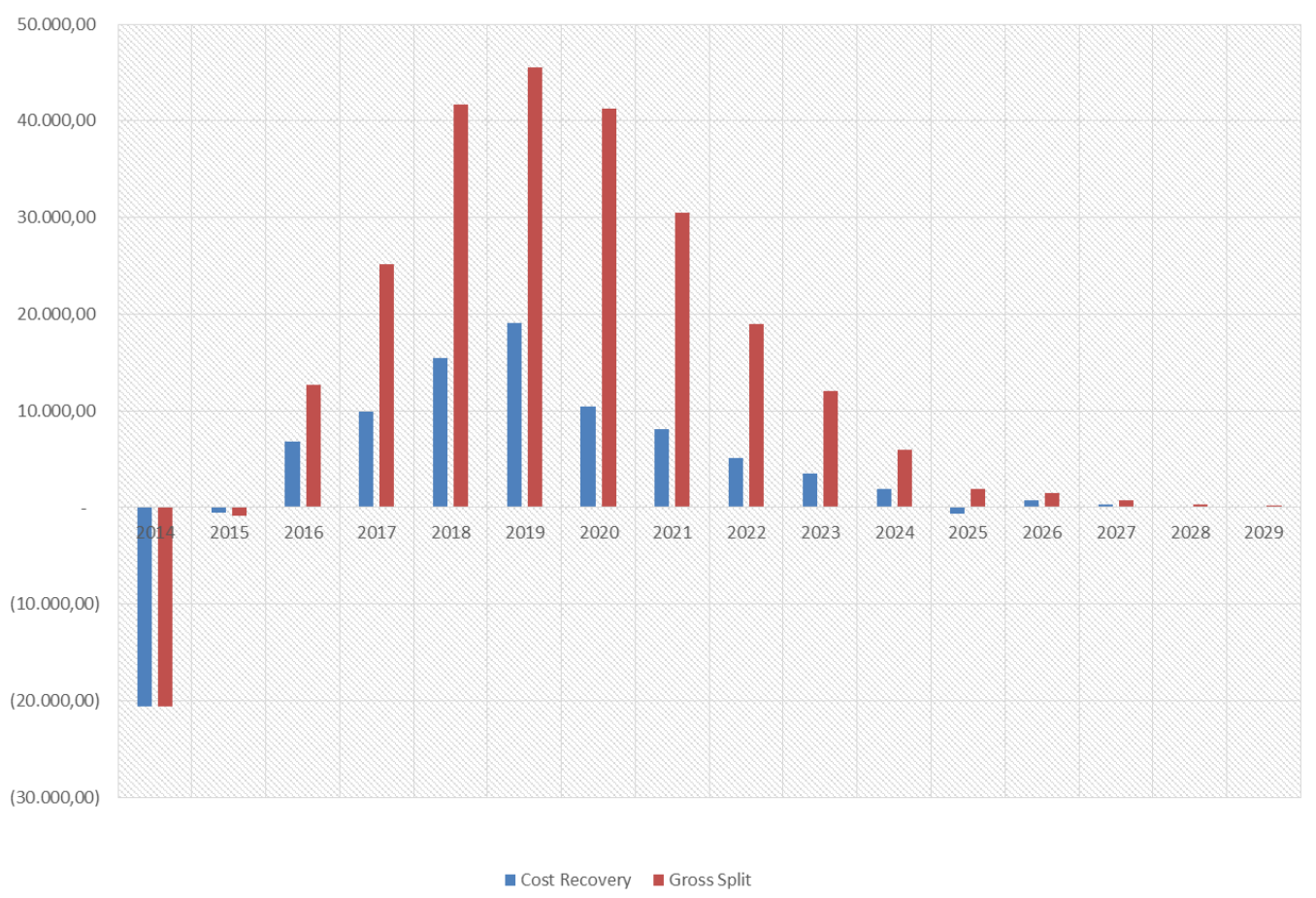

Gambar-5: Profil Cash Flow Gross Split and Cost Recovery

From the comparison of cash flow above between cash flow Cost Recovery and cash flow Gross Split, it can be seen that the cash flow with the Gross Split Product Sharing Contract is much greater than the cash flow Cost Recovery. Next will be a comparison of the NPV, IRR and BEP indicators for these two PSC schemes, as follows:

Table-13: Comparison of BEP IRR NPV Value Indicators

\begin{tabular}{|l|l|l|l|}
\hline & Cost Recovery & Gross Split & \\
\hline NPV @ 10\% & $54,603.64$ & $197,435.99$ & MUSD \\
\hline IRR & 47,15 & 85,84 & $\%$ \\
\hline BEP & 2,99 & 2,18 & Year \\
\hline
\end{tabular}

From Table-13, it can be seen that the PSC Gross Split scheme is more feasible compared to using the Product Sharing Contract Cost Recovery scheme

\section{Sensitivity Analysis}

The analysis was carried out on the Product Sharing Contract Gross Split scheme with the NPV and
IRR indicators. From these two indicators, changes were made to the amount of production data, oil price, capex and opex where each analysis can show that from each field or from the work contract, there has been an increase or decrease of $-25 \%, 0 \%$ to $25 \%$. 


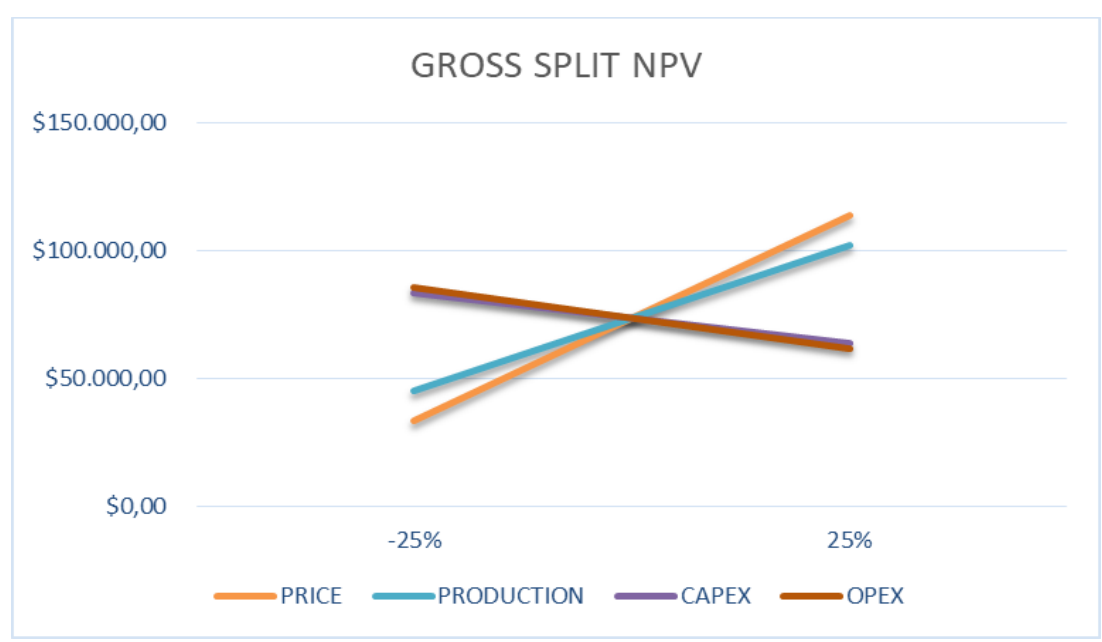

Fig-6: Diagram NPV Gross Split

From Figure 6 above, it is known that a significant indicator affects the NPV value of the Product Sharing Contract Gross Split scheme, namely significant production data and oil prices when obtaining an increase of $25 \%$.

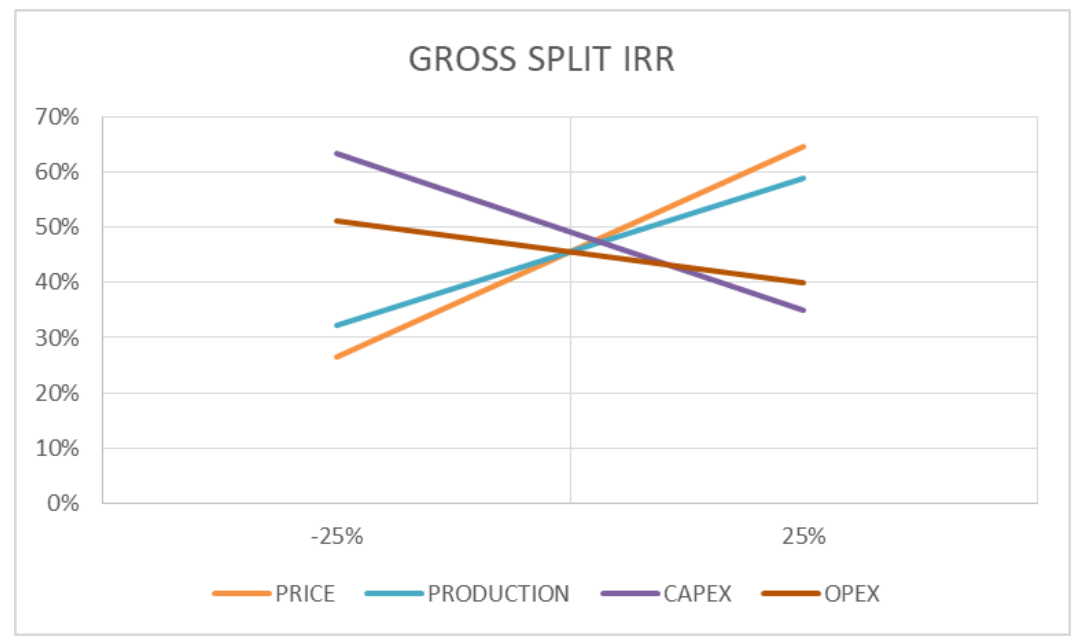

Fig-7: Diagram IRR Gross Split

In Figure-7, it is shown that the indicator that most influences the IRR value on the PSC Gross Split scheme is Capex, if a $25 \%$ reduction is carried out. In the PSC Cost Recovery scheme, things of the same type are also carried out by looking at factors or indicators of increase and decrease with sensitivity analysis on the NPV, IRR

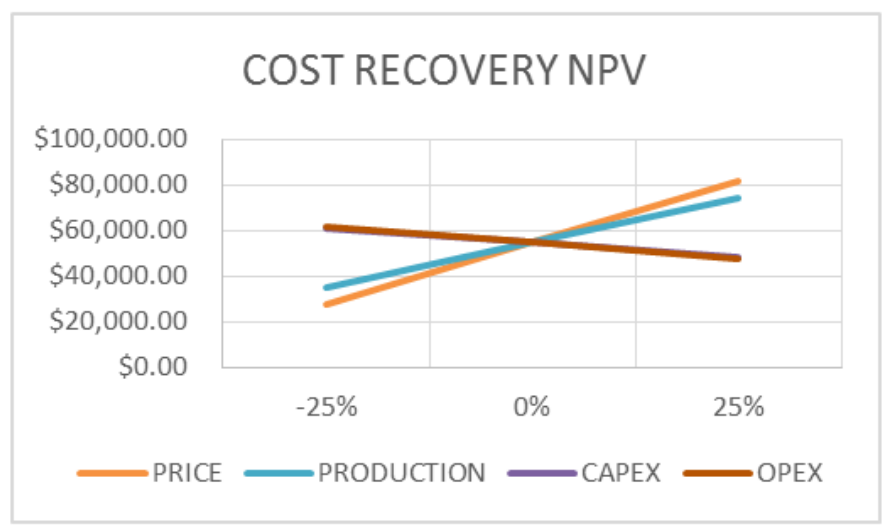

Fig-8: Diagram NPV Cost Recovery 
The diagram above shows that the oil price with a percentage of at least $25 \%$ has a significant effect on NPV with the Product Sharing
Contract Cost Recovery scheme. Furthermore, a sensitivity analysis will be carried out on the IRR of the PSC Cost Recovery scheme.

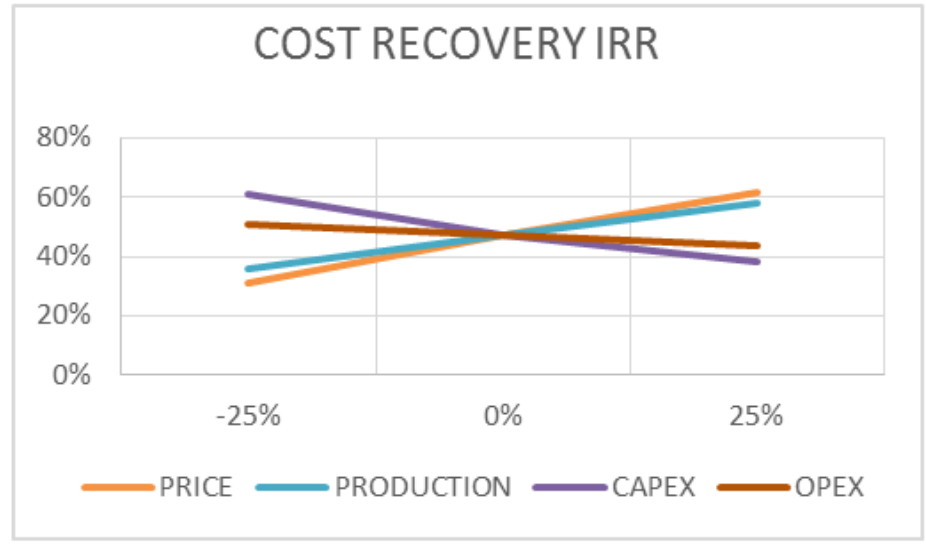

Fig-9: Diagram IRR Cost Recovery

The diagram above shows that a $25 \%$ decrease in the value of Capex will affect the IRR with the Cost Recovery scheme, meaning that the IRR will affect the investment in contracts or field projects.

\section{DISCUSSION}

Based on the calculations that have been carried out at the ETB Field using the Gross Split scheme which will replace the Cost Recovery scheme, then the researchers conducted an analysis of the company's production data, oil prices that are running with data processing using the calculation of the two schemes against NPV, IRR, BEP, KKKS and GOI and sensitivity analysis. According to the Table-11 it can be seen that the revenue obtained by the government by using the scheme PSC Cost Recovery $\$ 876,617.91$ and scheme PSC gross split of $\$ 466,137.97$, while revenue gained contractor by using a scheme Product Sharing Contract Cost Recovery \$ $515,424.75$ and schemes Product Sharing The gross contract split is $\$ 402,058.17$, this means that it is more profitable to use a gross split scheme compared to cost recovery, however this is not sufficient to prove that the Product Sharing Contract Cost Recovery scheme is feasible to implement.

For comparison the next, will focus on cashflow between the two schemes Product Sharing Contract are as shown in Table-12 it can be seen that by using the Product Sharing Contract (PSC) Cost Recovery $\$ 60,064.00$ and schemes Product Sharing Contract (PSC) gross split of $\$ 217,179.58$ this can It can be seen that the cash flow with PSC Gross Split is much greater than the cash flow Cost Recovery. Next will be a comparison of the NPV, IRR and BEP indicators against the Product Sharing Contract cost recovery scheme and gross split where the NPV uses the cost cost recovery and gross split scheme, where the NPV with the cost recovery scheme is $\$ 54,603.64$ while the NPV for the gross split scheme is $\$ 197,435.99$. Then the IRR for the cost recovery scheme is $47.15 \%$ while the gross split scheme is $85.84 \%$. Furthermore, the BEP for the cost recovery scheme is 2.99/ year while the gross split scheme is 2.18/year based on a comparison with the NPV, IRR and BEP indicators.

After the previous analytical then performed a sensitivity analysis in which of the image 6 can be seen, the indicators most influence the NPV value in the schematic Product Sharing Contract (PSC) Gross Split ie data significant production and oil prices gained value peningkata $n$ by $25 \%$ while based Figure- 8 shows that the oil price with a percentage of at least $25 \%$ has a significant effect on NPV with the PSC Cost Recovery scheme. Next will be a sensitivity analysis on the IRR scheme PSC Cost Recovery, which in the Figure-7 it can be seen that the indicator most affect the IRR on the scheme Product Sharing Contract Gross Split is Capex which when done will run intolowering $25 \%$, then scheme PSC Cost Recovery with analysis sensitivity to the IRR shows that the percentage of $25 \%$ decline in the value of capital expenditure so that means IRR $\mathrm{p}$ effect on the investment there is a contract or project the field. So that it can be concluded that the contracts in the field with a scheme ETB Product Sharing Contract (PSC) Gross Split more feasible to work with using the scheme be compared Product Sharing Contract (PSC) Cost Recovery.

This is supported by the results of interviews obtained with ETB Field Subcontractors and other informants who are presented in several form of quotations, namely " We are currently being directed to change the scheme, but the strength of the change in the Gross Split scheme for our field / block does not have a significant impact, meaning that it is still difficult with the field as we have to switch to Gross Split, where we 
Ravena Galuh Karisma \& Nengzih Nengzih., Saudi J Econ Fin, Mar, 2021; 5(3): 114-125

have to be as efficient as possible on operations. Our location and field are very difficult to reach, so the costs that come out are difficult to be streamlined, there is a market for that coverage. "The informant further stated, "What is certain is that there is a mutually beneficial system between the two parties and the government hopes that more investors can join in. In fact, the change in this scheme is to fend off the public's assessment of the PSC Cost Recovery scheme which is considered skewed. With the change in the Gross Split Product Sharing Contract (PSC) scheme, the government and contractors do not need to be preoccupied with providing explanations about the increase in Product Sharing Contract (PSC) Cost Recovery or the possibility of irregularities .

Then the third informant said, "In actuality, all oil and gas fields cannot be generalized. Our oil and gas fields still tend to be new, so new oil and gas fields tend to have large uncertainties, so that the risk is also high, usually if this is the case management will choose to use the PSC Cost Recovery scheme. this is none other than, to invite investors to join and provide guarantees to them for a return on their investment. "

Fourth informant "In the calculation mechanism PSC Cost Recovery consists of CAPEX or Capital Expenditure which is issued in the form of investments in tangible goods (for example, purchasing manholes, buying turbines, buying vessels) and at the end of the contract, all of these purchases will become company assets. We also calculate drilling, lifting, exploration, construction using CAPEX. For the PSC Gross Split mechanism, the division is simpler, it only uses a base split. Where the implementer of the work may only get a change if the production reaches the target and the executor of the work gets a profit if it is done as efficiently as possible. "

\section{CONCLUSION}

Based on the results of the analysis between the two Product Sharing Contract Gross Split and Cost Recovery schemes on the ETB field, it can be seen that the revenue earned by the government (government) using the Product Sharing Contract Cost Recovery scheme is $\$ 876,617.91$ and a gross split Product Sharing Contract is $\$ 466,137.97$, while the revenue earned by contractors using the Product Sharing Contract Cost Recovery scheme is $\$ 515,424.75$ and the gross split Product Sharing Contract scheme is \$ 402,058.17. Furthermore, on Cashflow using the \$ 60,064.00 Product Sharing Contract Cost Recovery scheme and the gross split Product Sharing Contract scheme of $\$ 217,179.58$. Then the comparison indicator between the NPV and the cost recovery scheme is $\$$ $54,603.64$ while the NPV for the gross split scheme is \$ $197,435.99$.

Then the IRR for the cost recovery scheme is $47.15 \%$ while the gross sharing scheme is $85.84 \%$.
Furthermore, BEP for the cost recovery scheme is 2.99 / year while the gross sharing scheme is 2.18 / year based on a comparison with the NPV, IRR and BEP indicators, it can be concluded that the contract in the ETB field with the Gross Split Product Sharing Contract (PSC) scheme is more feasible to be done in a comparison using the Product Sharing Contract (PSC) Cost Recovery scheme. The sensitivity analysis of the NPV value on the PSC Gross Split scheme is significant data and the oil price when it gets an increase of $25 \%$ while the oil price with a percentage of at least $25 \%$ has a significant NPV effect with the PSC Cost Recovery scheme.

Next IRR with the PSC Cost Recovery scheme, it can be seen that the indicator that affects the IRR value on the PSC Gross Split scheme is Capex where if it is done it will experience a decrease of $25 \%$, then the PSC Cost Recovery scheme with IRR sensitivity analysis shows that the percentage decrease is $25 \%$ the value Capex, so this means that the IRR has an effect on the investment in the contract or field project. This means that the PSC Gross Split is still superior to PSC Cost Recovery and is feasible to implement because this indicator shows sufficient sensitivity.

It is recommended to look for the impacts that occur on changes in the PSC scheme to the ETB field because there are still many things that need to be initiated so that this change is indeed positive but still leaves negative things, by implementing the PSC Scheme Split scheme the decision-making process is faster and practically, the employer community is much diminished or even non-existent. There is no more political process in decision making, reducing the complexity of the audit (only done for tax audits. Then a more in-depth study of progress is needed for the next 15 years that have been running So that cash flow and operations balance each other. When it has switched to Gross Split, in order to examine more deeply about the descriptions that will be received by the contractor. What limitations can be added or added to the number of splits both for contractors and for the government.

\section{REFERENCES}

1. Latief, H. (2012). Islamic charities and social activism: welfare, dakwah and politics in Indonesia (Doctoral dissertation, Utrecht University).

2. Nengzih. (2016). The Influence of Corporate Governance, Tax Avoidance, Leverage, and Company Size to Earnings Management: Empirical Study from Indonesia's Banking Companies 2015-2017. Schollars Bulletin, ISSN 2412-897X

3. Hidayah, N., Nugroho, L., \& Badawi, A. (2018, December). Socialization and Training For Productive Household Budget For Household Mother In Meruya Selatan Village (Jakarta Barat, 
Indonesia). In ICCD (Vol. 1, No. 1, pp. 523-527).

4. Salim, S., \& Gould, A. (2003). Improved astrometry and photometry for the Luyten catalog. II. Faint stars and the revised catalog. The Astrophysical Journal, 582(2), 1011.

5. Masita, C. M. (2012). Analysis of Revenue Recognition for Natural Gas Cooperation Contract Contractors according to Production Sharing Contracts and International Financial Reporting Standards (Case Study at BP BERAU Ltd.). Thesis. Depok. University of Indonesia.

6. Roach, R. C., Hackett, P. H., Oelz, O., Bärtsch, P., Luks, A. M., MacInnis, M. J., ... \& Lake Louise AMS Score Consensus Committee. (2018). The 2018 Lake Louise acute mountain sickness score. High altitude medicine \& biology, 19(1), 46.

7. Issa, A., Ramadugu, K., Mulay, P., Hamilton, J., Siegel, V., Harrison, C., ... \& Boehmer, T. (2018). Deaths related to Hurricane Irma-Florida, Georgia, and North Carolina, September 4October 10, 2017. Morbidity and Mortality Weekly Report, 67(30), 829.

8. Handika, I. (2019). Influence of PSC Changes in The Upstream Sector From Cost Recovery System Into Gross Split Towards The Obligation to Pay Land and Building Tax. Journal of Mimbar Hukum, 31(1):3.

9. Rizki, A. K. D., Asri, N., \& Havid, P. (2019). Calculation of Contracts for PSC Indonesia and PSA Libya in one Juve Field. National Expert Seminar 2 Books 1 Science and Technology.

10. Giranza, M. J., Bergman, A. (2018). Indonesia's New Gross Split PSC is more Superior than Previous Standard PSC. Journal of Economics, Business and Management, 6(2).

11. Galuh, G. N., \& Wustrari, L. M. (2018). Impact of Individual Readiness and Organizational Readiness to Change on Affective Commitment to Change. Journal of Infrastructure \& Facilities Asset Management, 2(2).

12. Hernandoko, A. (2018). Implications of Changing Production Sharing Contracts (Product Sharing Contracts) to Gross Split Production Sharing Contracts on Oil and Gas Investments in Indonesia. Private Journal of Law, 6(2).
13. Bryant, D. M., Johnson, K., DiTommaso, T., Tickle, T., Couger, M. B., Payzin-Dogru, D., ... \& Whited, J. L. (2017). A tissue-mapped axolotl de novo transcriptome enables identification of limb regeneration factors. Cell reports, 18(3), 762-776.

14. Ariyon, M., \& Eka K. D. (2018). Economic Comparative Study of Marginal Oil Field Development Using Product Sharing Contract and Gross Split. National Seminar on Technology and Engineering.

15. Rulandari, N., Rusli, B., Mirna, R., Nurmantu, S., \& Setiawan, M. I. (2018, November). Valuation of production sharing contract cost recovery vs gross split in earth oil and gas cooperation contracts in Indonesia and the aspect of public service. In Journal of Physics: Conference Series (Vol. 1114, No. 1, p. 012132). IOP Publishing.

16. Sahroini, N., \& Firman, A. (2018). Innovation In Operations And Project Development Strategy at PHE ONWJ To Sustain The Business In Implementing Gross Split Production Sharing Contract. Jurnal Manajemen Bisnis, 9(1), 1-24.

17. Bergman, Y. S., Horenczyk, G., \& AbramovskyZitter, R. (2017). Perceived discrimination and well-being among the Ultra-Orthodox in Israel: The mediating role of group identity. Journal of Cross-Cultural Psychology, 48(9), 1320-1327.

18. Cuthbertson, D., Barriuso, J., Pizanais, M., Jaffa, M., Lamarca, A., Vivian, G., ... \& Yip, V. (2018, November). The impact of $68 \mathrm{Ga}$-based PET-CT scanning on the management of patients with sporadic pancreatic neuroendocrine tumours (pNETs). In Endocrine Abstracts (Vol. 60). Bioscientifica.

19. Ogunleye, T. A. (2015). A Legal Analysis of Production Sharing Contract Arrangements in the Nigerian Petroleum Industry. Journal of Energy Technologies and Policy, 5(8), 1-10.

20. Puspita, A. R. M. (2017). Analysis of Cost Recovery in Oil and Gas Management Cooperation Contracts (Case Study of PT Pertamina EP).

21. Arifin, K. Z. A. (2014). Effect of Cost Recovery on Company Revenue and Goverment Take at PT Chevron Pacific Indonesia. Management Application Journal. 